\title{
The Distribution of Kidney Tumors in Our Hospital, The Relationship Between Pathological Stage, Nuclear Grade and Tumor Diameter: Analysis of 140 Cases
}

\author{
Hastanemizdeki Böbrek Tümörlerinin Dağılımı, Patolojik \\ Evre, Nükleer Derece ve Tümör Çapı IIle İlişkisi: 140 \\ Olgunun Analizi
}

Nusret Akpolat ${ }^{2}$

Usak University, Faculty of Medicine, Training and Research Hospital, Department of Pathology, Usak, Turkey

'Inönü University, Faculty of Medicine,

Department of Pathology, Malatya, Turkey

Geliş Tarihi/Received: 16 August 2018 Kabul Tarihi/Accepted: 26 December 2018

Address correspondence to: Sirin Kucuk, Usak University, Faculty of Medicine, Training and Research Hospital, Department of Pathology, Usak, Turkey

e-mail: ata2012irin53@yahoo.com

\section{ORCID}

Sirin Kucuk

https://orcid.org/0000-0002-8552-2101
Sirin Kucuk ${ }^{1}$

Öz

Amaç: En sık görülen malign böbrek tümörü olan renal hücreli karsinom (RCC), yetişkinlerde görülen tüm malign tümörlerin \%2-4'ünü, tüm malign böbrek tümörlerinin ise \%80-90'inini oluşturur. Bu çalışmada hastanemizdeki renal tümörlerin dağılımı, patolojik evreleme, nükleer derece ve tümör çapı gibi prognostik faktörlerin literatür bilgileri eşliğinde tartışılması amaçlanmıștır.

Hastalar ve Yöntem: Fırat Üniversitesi Tıp Fakültesi Patoloji Anabilim Dalında 1988-2009 yılları arasında retrospektif olarak 140 böbrek tümörü saptandı ve bu tümörlerin daha önceki tanıları, histolojik dereceleri ve patolojik evreleri yeniden değerlendirildi, son tanıları çalışmada esas alındı. RCC'ların patolojik evreleme (pT)'de TNM sınıflaması ve nükleer derecelendirme (grade)'de Fuhrman nükleer derecelendirme (FND) sistemi kullanıldı. Hastaların cinsiyetleri ve yaş aralıklarına göre farklı alt gruplara ayrıldı.

Bulgular: Çalışmamızda ortalama yaş genel literatürden nispeten genç bir popülasyonu (ortalama yaş 57) içermekte ve erkek baskınlığı (erkek/kadın:1,1) göstermektedir. Çalışmadaki RCC'Iar arasında en büyük çapa sahip olan papiller tip $(9.78 \mathrm{~cm})$, en küçük çapa sahip olan ise klasik tipti. Benign, borderline ve malign tümör tanıları ile çaplar arasında ise istatistiksel olarak anlamlı ilişki saptandı $(p=0.023)$. RCC vakalarının yaklaşık dörte birinin (\%21,6, pT3a-3b) yüksek patolojik evreli olduğu görüldü. Artan nüklee derece ile çap arasında doğru orantı ve istatistiksel olarak anlamlı bir ilişki izlendi $(p=0,002)$.

Sonuç: Prognozu etkileyen faktörlerin başında patolojik evre, nükleer derece ve çap yer almaktadır. Bizim çalışmamızda da olduğu gibi eski yılları içeren ve örneklemesi yeterli düzeyde yapılmayan retrospektif çalışmalarda özellikle pT2'nin üzerinde evreye sahip tümörlerde tümör çapı patolojik evrelemeye alternatif bir prognostik faktör olarak kullanılabilir.

Anahtar Kelimeler: Malign böbrek tümörleri, spesifiye edilmemiş / borderline / belirsiz tümörler onkositom, patolojik evre, nükleer derece, tümör çapı

\section{Abstract}

Aim: The renal cell carcinoma (RCC), which is the most frequently seen malign renal tumor, consists of $2-4 \%$ of all the malign tumors seen among adult individuals and $80-90 \%$ of all the malign renal tumors. The recurrence is seen in $40 \%$ of the cases, and the metastasis despite the early diagnosis was detected in $50 \%$ of cases. In present study, it was aimed to distribution of renal tumors in our hospital, discuss the prognostic factors such as the, pathological stage, nuclear grade and tumor diameter accompanied by literature information.

Patients and Methods: By retrospectively scanning the records of Pathology Department of Medical Faculty, Firat University, for the period between 1988 and 2009, 140 renal tumor cases were determined and the previous diagnoses, histological degrees, pathological stages of these cases were evaluated and the final diagnoses were taken as base in the present study. In pathologically staging (pT) of RCCs, TNM classification was used, whereas Fuhrman nuclear grading (FNG) was used in nuclear grading procedure. The patients were divided into different groups based on their genders and ages.

Results: When compared to the literature in terms of the mean age, the present study involves relatively young population (mean age 57), and the majority was male (male/ female:1.1). In the present study, the RCCs with largest diameter were papillary type $(9,78 \mathrm{~cm})$ ones, whereas the RCCs with lowest diameter values were classic type. A statistically significant relationship was observed between the benign, borderline and malign tumor diagnoses and diameters $(p=0.023)$. It was determined that approximately one-four of RCC cases were in highly pathological stage $(21,6 \%$, pT3a-3b). A direct proportional and statistically significant relationship was found between nuclear grade and diameter $(p=0,002)$.

Conclusion: Pathological stage, nuclear grade and diameter are the leading factors affecting the prognosis. As in our study, in retrospective studies involving old ages and not enough sampling, tumor diameter may be used as an alternative prognostic factor for pathological staging in tumors with a stage above pT2.

Key words: Malign renal tumors, oncocytoma, unspecified / borderline / uncertain tumors, pathological stage, nuclear grade, tumor diameter

Cite this article as: Kucuk S, Akpolat N. The Distribution of Kidney Tumors in Our Hospital, The Relationship Between Pathological Stage, Nuclear Grade and Tumor Diameter: Analysis of 140 Cases. Selcuk Med J 2019;35(2): 105-112
Disclosure: None of the authors has a financial interest in any of the products, devices, or drugs mentioned in this article. The research was not sponsored by an outside organization. All authors have agreed to allow full access to the primary data and to allow the journal to review the data 


\section{INTRODUCTION}

Most of the renal tumors are malign ones and the most frequently seen type of malign renal tumors is the renal cell carcinoma (RCC). It constitutes 80 $90 \%$ of all the renal tumors (1-8). Although RCC may be seen at any age, RCC peaks at 6th and 7th decade and it is most frequently seen in the male gender $(1-3,5,6)$. RCCs have different genetic and epigenetic anomalies, and they constitute a histopathologically and molecularly heterogeneous tumor group (9). RCCs have been re-classified based on tumor morphology, cell genetics, histological pattern, immunohistochemical and epidemiological characteristics with an arrangement by the 2016 World Health Organization (WHO) according to new studies and data on RCCs. The revisions made in classification enabled better understanding the characteristic features of renal cell tumors (3,5,7-10). The most frequently seen ones among these types are clear cell (classic type) RCC (65-75\%), papillary RCC (15-20\%), chromophobe RCC (5-7\%), multilocular cystic renal neoplasm of low malignant potential and oncocytoma (3,5,7-9). Some of the newly defined RCC subtypes are multilocular cystic renal neoplasia with low malignant potential, MiT (microphtalmi transcription factor) family, TRCC (translocation $\mathrm{RCC}$ ), and ACD (Acquired cystic disease) related $\operatorname{RCC}(3,7-9)$.

RCC has a bad prognosis and some of the factors determining the prognosis are clinical stage, histopathological subtype, nuclear grade, lymphovascular invasion, sarcomatoid component, and the presence of necrosis and granular/ eosinophilic cytoplasm (1-3,5,6,9,11,12). For instance, the necrosis is more widely seen among clear-cell RCC cases. The tumors with diameter higher than $4 \mathrm{~cm}$ are more frequently seen and accompanied by a higher level of nuclear grade (10). Moreover, it is very important to evaluate the rate of necrosis among clear-cell RCC cases, and the 5-year survival rate of cases with tumor necrosis constituting more than $10 \%$ of all the tumor tissue (6). 5-year survival rate of RCC cases is $50 \%$, and 10 -year survival rate is $33 \%$. The recurrence is seen among $40 \%$ of patients. The metastasis is found in $50 \%$ despite the early diagnosis $(2,11)$. 5-year survival rate of metastatic cases ranged between 0 and $13 \%$, whereas the survival rate increases up to $50-90 \%$ among the local tumors (5). As a classic information, the clearcell RCCs have worse prognosis than the papillary and chromophobe RCCs (10). However, despite the increasing incidence of disease in recent years, the survival durations increased together with the early diagnosis of lesion by using radiological methods as well as the increasing use of percutaneous biopsies $(5,10,13,14)$. In this study, it was aimed to distribution of renal tumors in our hospital, discuss the prognostic factors such as the, pathological stage, nuclear grade and tumor diameter accompanied by literature information.

\section{PATIENTS AND METHODS}

140 renal tumor cases diagnosed in 21-year period were retrospectively involved in this study. The previous diagnoses, histological degrees, and pathological stages of 140 renal tumors cases were re-evaluated, and the final diagnoses were taken as base in this study. In pathologically staging (pT) of RCCs, TNM classification was used, whereas Fuhrman nuclear grading (FNG) was used in nuclear grading procedure. The patients were divided into different groups based on their genders and ages. The statistical analyses were performed in SPSS12.0 software by using Chi-Square and Correlation tests. Statistical significance was set to be $p \leq 0.05$.

\section{RESULTS}

Out of 140 renal tumor cases undergone radical nephrectomy, 77 (55\%) cases were male and 63 $(45 \%)$ cases were female (Table 1$)$. The ages of cases ranged between 8 and 82 years, and the mean age was calculated to be 57.140 renal tumor cases were divided into 3 subgroups by their age groups. There were $25(18 \%)$ cases aged 45-year and younger, 64 $(46 \%)$ cases aged between 46 and 65 years, and 51 (36\%) cases aged 65-year and older. The age groups of primary malign renal tumor and the distribution are presented in (Table 2). The renal tumors were divided into 3 subgroups by the diameters of tumors; $40(28.5 \%)$ tumors with $4 \mathrm{~cm}$ diameter and less, 50 $(35.7 \%)$ tumors with $5-7 \mathrm{~cm}$ diameter, and 50 (35.7\%) tumors with $7 \mathrm{~cm}$ and higher diameter.

Out of 140 renal tumors, 121 (86.4\%) cases were primary malign renal tumor, $2(1.4 \%)$ cases were multilocular cystic renal neoplasm of low malignant potential, $1(0,7 \%)$ case was epitheloid angiomyolipoma, $15(10.8 \%)$ cases were primary benign renal tumor, and $1(0.7 \%)$ case was secondary malign renal tumor. Secondary tumor had GIS origins and it was found to have renal metastasis. Out of these 124 primary malign renal tumors and unspecified / borderline / uncertain tumors, 71 (57.2\%) tumors were 
Table 1. Distribution of 140 tumors by the gender and prevalence of subtypes

\begin{tabular}{|c|c|c|c|}
\hline \multirow[t]{2}{*}{ Diagnosis } & \multicolumn{2}{|c|}{ Gender } & \multirow[t]{2}{*}{ Total (\%) } \\
\hline & Male & Female & \\
\hline Classic RCC & 33 & 38 & $71(50.7)$ \\
\hline Papillary RCC & 13 & 3 & 16(11.4) \\
\hline Chromophobe RCC & 8 & 7 & $15(11)$ \\
\hline \multicolumn{4}{|l|}{ Multilocular cystic renal neoplasm } \\
\hline of low malignant potential (\%) & 1 & 1 & $2(1.4)$ \\
\hline Unclassified RCC & 1 & 0 & $1(0.7)$ \\
\hline Mucinous tubular and spindle cell carcinoma & 0 & 1 & $1(0.7)$ \\
\hline Oncocytoma & 5 & 5 & $10(7.1)$ \\
\hline Angiomyolipoma & 0 & 5 & $5(3.5)$ \\
\hline Epitheloid angiomyolipoma & 0 & 1 & $1(0.7)$ \\
\hline Urothelial carcinoma & 13 & 1 & $14(10)$ \\
\hline Epidermoid carcinoma & 2 & 0 & $2(1.4)$ \\
\hline Malign fibrous histiocytoma & 1 & 0 & $1(0.7)$ \\
\hline Metastatic carcinoma & 0 & 1 & $1(0.7)$ \\
\hline Total & 77 & 63 & 140 \\
\hline
\end{tabular}

classic type RCC (Figure 1), 16 (13\%) tumors were papillary RCC (Figure 2), 15 (12.1\%) tumors were chromophobe RCC (Figure 3), 14 (11.3\%) tumors were urothelial carcinoma, $2(1.6 \%)$ tumors were multilocular cystic renal neoplasm of low malignant potential (unspecified / borderline / uncertain tumors), $1(0.8 \%)$ tumor was unclassified type, $1(0.8 \%)$ tumor was mucinous tubular and spindle cell tumor, 2 $(1.6 \%)$ tumors were epidermoid carcinoma, $1(0.8 \%)$ tumor was epitheloid angiomyolipoma (unspecified / borderline / uncertain tumors) and $1(0.8 \%)$ tumor was malign fibrous histiocytoma. Out of 15 benign renal tumors, $10(66.6 \%)$ tumors were oncocytoma (Figure $4)$, and $5(33.4 \%)$ tumors were angiomyolipoma (Table 1).

Among the RCCs in the present study, papillary type RCCs had the largest diameter and the classictype RCCs had the smallest diameters. The mean diameter of classic RCC cases was $6.67 \mathrm{~cm}$, whereas the mean diameters of papillary and chromophobe RCCs and oncocytoma were found to be $9.78 \mathrm{~cm}$, $8.18 \mathrm{~cm}$, and $5.9 \mathrm{~cm}$, respectively. A statistically significant relationship was found between tumor diameters and diagnoses $(p=0.023)$ (Table 3). 106 primary malign and unspecified / borderline / uncertain renal tumors were re-evaluated based on the TNM classification, and then they were divided into 6 subgroups. Out of these 106 primary malign renal tumor, there were 20 (18.9\%) pT1a tumors, 33 (31.1\%) p T1b, 24 (22.7\%) pT2, 26 (24.5\%) pT3a, and $3(2.8 \%)$ pT3b (Table 4$)$, whereas 1 case was GIScaused adenocarcinoma metastasis. 3 of resting 14 urothelial carcinoma cases were pT1, 4 cases were pT2 and 7 cases were pT3. RCC cases were divided into 4 subgroups based on FNG, whereas they were classified under 4 subgroups according to WHO 2016 in urothelial carcinoma assessment system. Out of these malign renal tumors (except chromophobe

Table 2. Distribution of renal cell carcinomas and unspecified / borderline / uncertain tumor ( $\left.{ }^{*}\right)$ by the age groups

\begin{tabular}{|c|c|c|c|c|}
\hline Diagnosis & \multicolumn{3}{|l|}{ Age } & Total \\
\hline Classic RCC (\%) & $12(16.9)$ & $35(49.3)$ & $24(33.8)$ & 71 \\
\hline Papillary RCC (\%) & $4(25)$ & $7(43.8)$ & $5(31.3)$ & 16 \\
\hline Chromophobe RCC (\%) & $2(13.3)$ & $7(46.7)$ & $6(40)$ & 15 \\
\hline Multilocular cystic renal neoplasm & & & & \\
\hline of low malignant potential $\left({ }^{*}\right)(\%)$ & $1(50)$ & 0 & $1(50)$ & 2 \\
\hline Unclassified RCC (\%) & 0 & $1(100)$ & 0 & 1 \\
\hline Mucinous tubular and spindle & & & & \\
\hline cell carcinoma $(\%)$ & 0 & $1(100)$ & 0 & 1 \\
\hline Total $(\%)$ & $19(17.9)$ & $51(48.1)$ & $36(34)$ & 106 \\
\hline
\end{tabular}




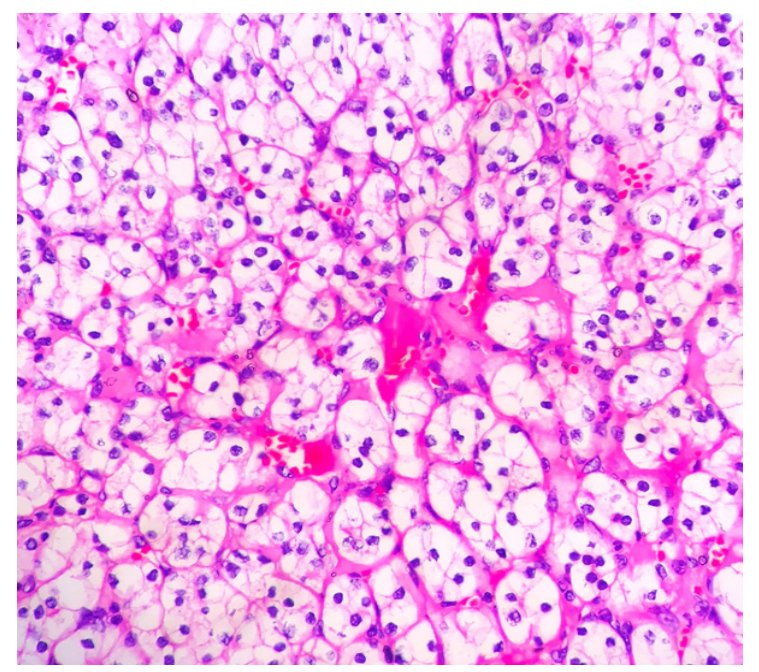

Figure 1. Clear cell RCC sample with acinar growth pattern, fine vascularized, divided by fibrous septa, involving low amount of stroma, HEx100

RCC) and unspecified / borderline / uncertain tumor, there were $12(13,2 \%)$ FNG 1, $48(52,7 \%)$ FNG 2, $23(25,3 \%)$ FNG 3, and 8 (8,8\%) FNG 4. Out of resting 19 malign renal tumors, there were 4 grade 1 urothelial carcinoma, 7 grade 2 urothelial carcinoma, 6 grade 3 urothelial carcinoma, 1 poor differentiated epidermoid carcinoma, and 1 moderate differentiated epidermoid carcinoma. When RCCs were examined from statistical aspect, no statistically significant relationship was determined between diagnosis,

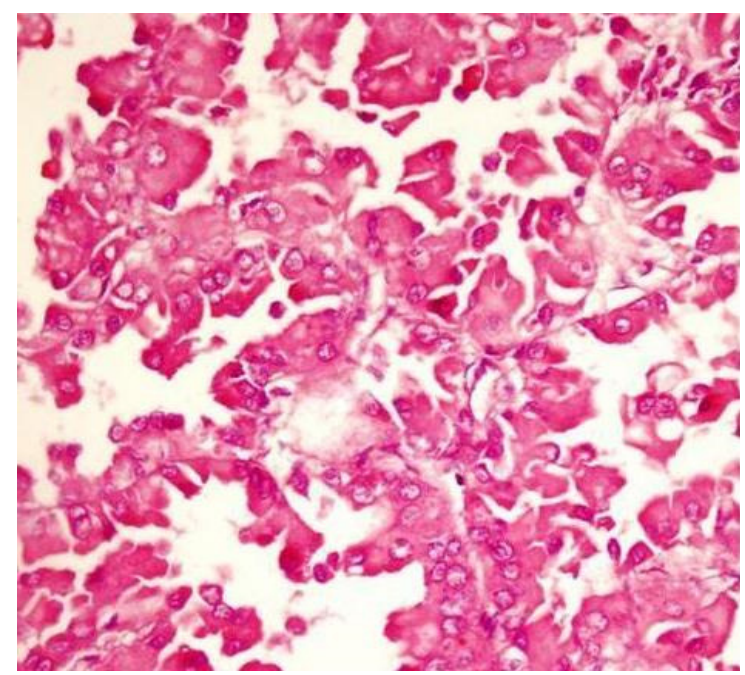

Figure 2. Papillary RCC sample with papillary growth pattern, fine fibrilovascular core, wide eosinophilic cytoplasm, and consisting of cells with nucleolus specificity, HEx100

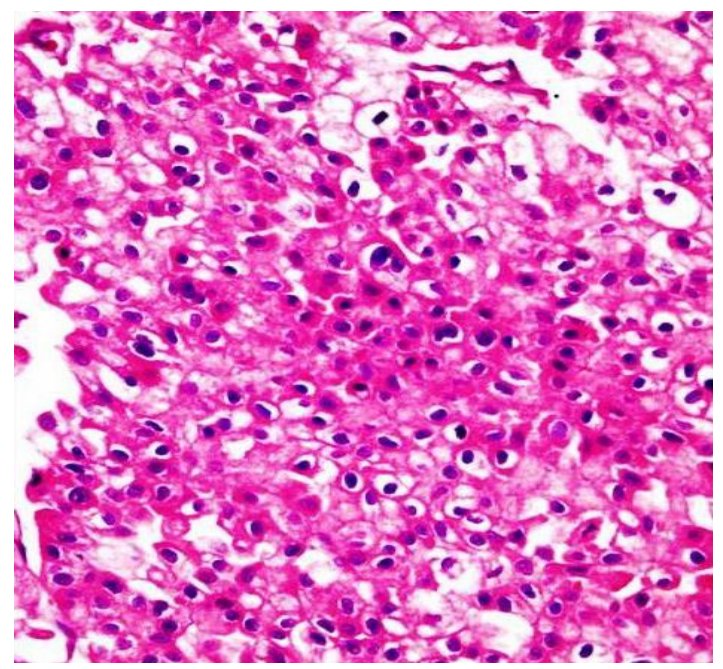

Figure 3. Chromophobe RCC sample with solid growth pattern, eosinophilic cytoplasm, including perinuclear halo, having hyperchromatic nucleus round-edged (partly cornered), and consisting of cells with irregular border, HEx100

nuclear grade, and tumor diameter ( $p>0.05)$. 50\% of papillary RCC cases and $46.7 \%$ of chromophobe RCC cases have diameter of $7 \mathrm{~cm}$ and higher, whereas classic RCCs were distributed equally in all three age groups. However, no statistically significant relationship was found.

However, no significant relationship was found

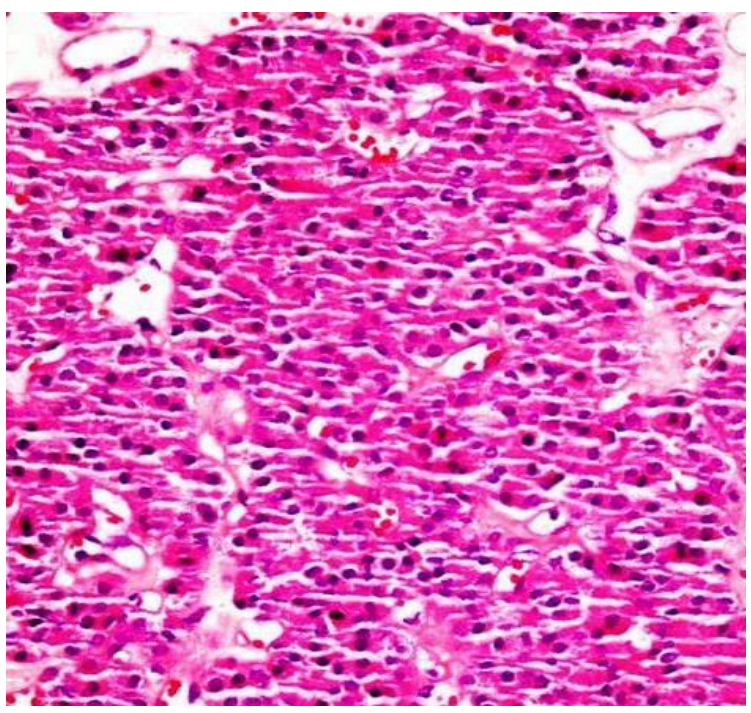

Figure 4. Oncocytoma sample with solid and nested pattern, having round-polygonal shape, including eosinophilic cytoplasm, having round shape and regular borders, fine chromatin, and consisting of homogenous cells, HEx100 
Table 3. Relationship between diagnosis and tumor diameter in renal tumors.

\begin{tabular}{|c|c|c|c|c|c|c|}
\hline \multirow[b]{2}{*}{ Diagnosis } & \multirow[t]{2}{*}{ Number } & \multicolumn{3}{|c|}{ Tumor diameter } & \multirow[b]{2}{*}{ Max. } & \multirow[b]{2}{*}{ Range } \\
\hline & & Mean & Median & Min. & & \\
\hline Classic RCC & 71 & 6.67 & 6.0 & 2.4 & 18 & 15.6 \\
\hline Papillary RCC & 16 & 9.78 & 7.5 & 2.5 & 20 & 17.5 \\
\hline Chromophobe RCC & 15 & 8.18 & 6.0 & 2.8 & 21.5 & 18.7 \\
\hline Oncocytoma & 10 & 5.9 & 6.0 & 1.7 & 9 & 7.30 \\
\hline \multicolumn{7}{|l|}{$\begin{array}{l}\text { Multilocular cystic renal } \\
\text { neoplasm of low malignant }\end{array}$} \\
\hline potential (\%) & 2 & 5.25 & 5.25 & 3.5 & 7 & 3.5 \\
\hline Unclassified RCC & 1 & 7.5 & 7.5 & 7.5 & 7.5 & 0 \\
\hline Urothelial Carcinoma & 14 & 5.35 & 4.75 & 2 & 11 & 9 \\
\hline Angiomyolipoma & 5 & 5 & 5 & 4 & 6 & 2 \\
\hline Epiteloid angiomyolipoma & 1 & 11 & 11 & 11 & 11 & 0 \\
\hline \multicolumn{7}{|l|}{ Mucinous tubular and spindle } \\
\hline cell carcinoma & 1 & 8 & 8 & 8 & 8 & 0 \\
\hline Epidermoid carcinoma & 2 & 8.25 & 8.25 & 6.5 & 10 & 3.5 \\
\hline Malign fibrous histiocytoma & 1 & 9 & 9 & 9 & 9 & 0 \\
\hline Metastatic carcinoma & 1 & 14 & 14 & 14 & 14 & 0 \\
\hline Total & 140 & 7.06 & 6 & 1.7 & 21.5 & 19.8 \\
\hline
\end{tabular}

between diagnosis and pT. On the other hand, $46 \%$ of classic RCC cases were found to be stage pT2 and pT3a-b, $56.3 \%$ of papillary RCC cases to be pT2 and pT3a, and $53.3 \%$ chromophobe RCC cases to be pT2- pT3a-b. No statistically significant relationship was found between tumor diagnoses and $p T(p>0.05)$ (Table 4). A statistically significant relationship was found between nuclear grade and tumor diameter $(p=0,002)$. All of grade 1 tumors had $4 \mathrm{~cm}$ and $4-7 \mathrm{~cm}$ diameters, whereas $82,6 \%$ of grade 3 cases had $4-7 \mathrm{~cm}$ and $+7 \mathrm{~cm}$ diameters and All of of grade 4 cases had diameters higher than $4 \mathrm{~cm}$. Thus, a direct proportion was determined between nuclear grade and diameter (Table 5). No statistically significant relationship was found between nuclear grade and $\mathrm{pT}$ $(p=0,317)$ (Table 6$) .16 .7 \%$ of grade 1 tumors were pT3a, $27.1 \%$ of grade 2 pT3a and $2.1 \%$ were pT3b and there was no pT3b case among grade 4 tumors.

\section{DISCUSSION}

The renal cell carcinoma (RCC), which is the 7th or 8th most frequent malignity affecting the adults, are the most frequently seen malign renal tumors. Among the urological tumors, they are the 3rd most prevalent ones, and they constitute $2-4 \%$ of all the malign tumors seen among the adults $(1-5,10,11,15)$. They are prevalently seen between 6th and 7 th ages, and the male/female ratio is $2 / 1$. In a study of Sarah et al. (5), the mean age was calculated to be 57.18 years ( $S D= \pm 14.68$ years), and the male/ female ratio was reported to be 1.51 . In the present study, the mean age was 57 years and the male/ female ratio was found to be 1.1. The prevalence values of renal tumors reported in literature were as

Table 4. Relationship between diagnosis and tumor diameter in renal tumors.

\begin{tabular}{|c|c|c|c|c|c|c|}
\hline Diagnosis & pT1a & pT1b & pT2 & pT3a & pT3b & Total \\
\hline Classic RCC (\%) & $15(21.1)$ & $22(31)$ & $11(15.5)$ & $22(31)$ & $1(1.4)$ & 71 \\
\hline Papillary RCC (\%) & $2(12.5)$ & $5(31.3)$ & $7(43.8)$ & $2(12.5)$ & 0 & 16 \\
\hline Chromophobe RCC (\%) & $2(13.3)$ & $5(33.3)$ & $4(26.7)$ & $2(13.3)$ & $2(13.3)$ & 15 \\
\hline \multicolumn{7}{|c|}{$\begin{array}{l}\text { Multilocular cystic renal } \\
\text { neoplasm of low malignant }\end{array}$} \\
\hline potential $\left({ }^{*}\right)(\%)$ & $1(50)$ & $1(50)$ & 0 & 0 & 0 & 2 \\
\hline Unclassified RCC & 0 & 0 & $1(100)$ & 0 & 0 & 1 \\
\hline \multicolumn{7}{|l|}{ Mucinous tubular and } \\
\hline spindle cell carcinoma & 0 & 0 & 1 & 0 & 0 & 1 \\
\hline Total & 20 & 33 & 24 & 26 & 3 & 106 \\
\hline
\end{tabular}


Table 5. Relationship between nuclear grade and tumor diameter in renal cell carcinoma and unspecified / borderline / uncertain tumor

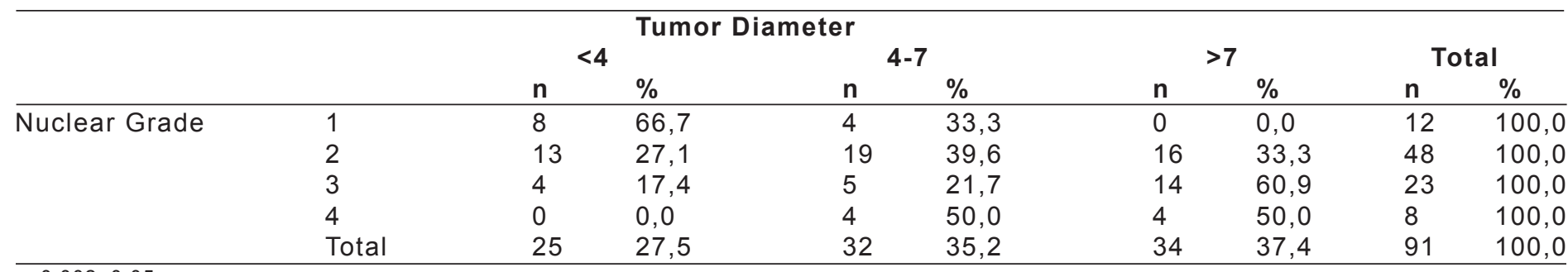

$p=0,002<0,05$

follows: classic RCC 60-75\%, papillary RCC 10-20\%, chromophobe RCC 5-10\%, unclassified type 6\%, Multilocular cystic renal neoplasm of low malignant potential $1-5 \%$, mucinous tubular and spindle cell tumor $\leq 1 \%$, epidermoid carcinoma $\leq 1 \%$, epitheloid angiomyolipoma $\leq 1 \%$, malign fibrous histiocytoma $\leq 1 \%$, oncocytoma $5 \%$, and angiomyolipoma $1 \%$ (1-3,5,7-10). These subgroups are named based on their dominant cytoplasmic characteristics, staining patterns, structural, morphological and the combination of them $(3,7-10,15)$. Moreover, the other parameters used in naming the tumors are anatomic location of tumor, relationship with renal diseases, microphtalmia transcription factor (MiT), and familial translocation CDD, and pathognomonic molecular alterations such as succinate hydrogenesisdischarged RCC (SDH-degenerated RCC) $(3,5,7,9)$. In the present study, the prevalence of renal tumors presented in Table 1 is closely similar to those presented in literature. In the present series, no tumor such as Bellini's collector channel carcinoma, renal medullar carcinoma, Xp11 translocation carcinoma, or carcinoma with neuroblastoma component was found.

Tumor size is an independent prognostic factor and the survival rate is lower among the cases with larger diameter (11). For instance; the survival rates of cases with pathological grades of pT1 $(\leq 7 \mathrm{~cm})$,
pT2 $(>7 \mathrm{~cm})$, pT3a, pT3b, and pT3c are 95-91\%, 80$70 \%, 66-53 \%, 52-43 \%$, and $43-42 \%$ (12). The mean size of tumor reported for chromophobe RCC in literature is $8-9 \mathrm{~cm}$, and these are the tumors having largest diameter among all the renal cell carcinomas. The mean diameter of papillary RCC (PRCC) is 6.4 $\mathrm{cm}$, whereas the mean diameters of classic RCC, oncocytoma, and angiomyolipoma are $8 \mathrm{~cm}, 6.5$ $\mathrm{cm}$, and $6 \mathrm{~cm}$, respectively (1-3). The diameters of frequently seen renal tumors determined in the present study are as follows; classic RCC: $6.67 \mathrm{~cm}$, papillary RCC: $9.78 \mathrm{~cm}$, chromophobe RCC: $8.18 \mathrm{~cm}$, oncocytoma: $5.9 \mathrm{~cm}$, and angiomyolipoma: $5 \mathrm{~cm}$. In the present study, the diameter of classic RCC cases showed equal distribution between the age groups, whereas almost half of chromophobe and papillary RCC cases had $4 \mathrm{~cm}$ or larger diameters. But, no statistically significant relationship was found between diagnosis and tumor diameter among the RCC cases.

In literature, more than $50 \%$ of classic RCC cases have pT3 or further stage extrarenal metastasis, whereas the pathological stage of chromophobe and papillary RCCs is low (1-3). Although more than $20 \%$ of renal oncocytomas are pT3, they are the benign tumor. This suggests that the solely use of tumor is insufficient in showing the tumor's biological activity. In the present study, more than half of chromophobe and papillary RCCs were found to have advanced

Table 6. Relationship between nuclear grade and PT in renal cell carcinoma and unspecified / borderline / uncertain tumor

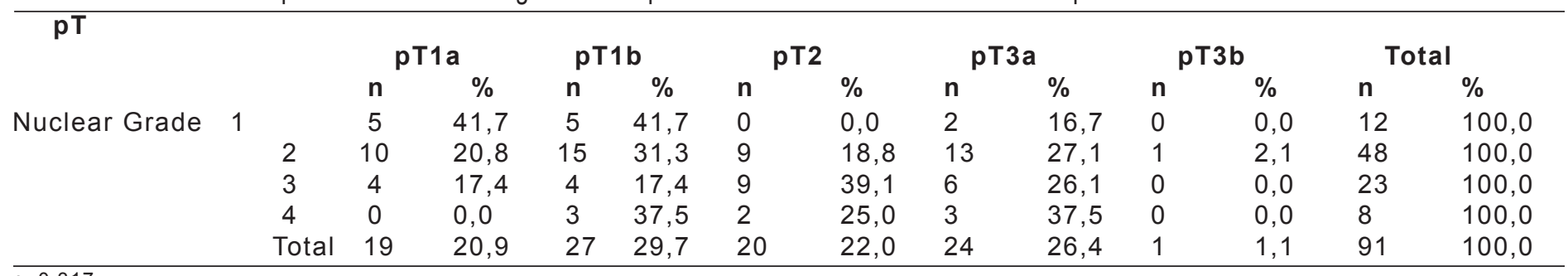


pathological stage, and this ratio was found to be higher than classic RCC in literature. However, no statistically significant relationship was found between RCC subtypes and $p T(p>0.05)$.

According to the Fuhrman Nuclear Grading (FNG) system that is widely used and recommended by International Society of Urological Pathology (ISUP) and World Health Organization (WHO), the tumors are divided into 4 groups. Grade 1-3 tumors are defined based on the nucleolus specificity, whereas Grade 4 tumors are defined based on nuclear pleomorphism, tumour giant cells, and the presence of rhabdoid or sarcomatoid differentiation $(1,3,6,7,12)$. FNG system is applied to clear cell RCC and papillary RCC but not to chromophobe RCC because of the presence of natural nuclear atypia $(3,6)$. FNG 3 and 4 were found to have higher rate of tumor recurrence when compared to FNG 1 and 2 (6). In their study on 338 patients, Shuji et al. reported the recurrence rate of pT1a RCC to be statistically significantly higher in Fuhrman nuclear grade 3 or 4 RCC patients when compared to Fuhrman nuclear grade 1 or 2 patients, whereas the authors reported no significant relationship between tumor recurrence and other clinicopathological parameters. For this reason, it was asserted that the nuclear grade could be used as a factor in estimating the tumor recurrence and metastasis after surgical intervention in pT1a RCC (6). In addition to the nuclear dimension and pleomorphism, another parameter used in determining the nuclear grade is the cytoplasmic eosinophilia/granularity. The grade of tumor increases together with the increase in these characteristics. For instance, the prognosis of classic RCCs with eosinophilic cytoplasm is much worse than that of classic RCCs with clear cytoplasm. Similarly, in papillary RCC divided into 2 groups as Type 1 and Type 2 based on the structural and cytological characteristics, Type 2 with eosinophilic cytoplasm has worse prognosis. The papillary RCC with low tumour grade, chromophobe RCC, and even oncocytoma, which is a benign renal tumor, may be seen at advanced pathological stage $(1-3,10)$. In the present study, the data indicating a significant relationship between nuclear grade and tumor diameter were obtained $(p=0,002)$. The nuclear grade was observed to increase together with the increasing tumor diameter. However, no significant relationship was observed between the nuclear grade and $\mathrm{pT}$.

When we compared our diagnoses to the previous diagnoses in this retrospective study, some of the diagnoses were altered. Most of these diagnostic differences were observed to originate from RCC and angiolipoma cases reported without determining the type and applying immunohistochemistry. When compared to the past, the immunohistochemical indicators are more effectively and widely used in addition to the morphology in distinguishing the renal tumors posing a diagnostic difficulty, and a more standardized reporting system is used. Under favor of these advancements, it can be stated that the accuracy of renal tumor diagnoses further increased. The main limitations of present study are the insufficiency of sampling from renal sinus and/or perirenal fat tissues macroscopically changing the stage in some of old dated cases, and thus the inability of making an accurate pT staging in some of cases. For this reason, it is believed that using the tumor diameter instead of $\mathrm{pT}$ would yield higher accuracy in the results of present study.

In conclusion, we re-evaluated renal tumors and then compared our clinic-pathologic findings to the literature. We achieved reliable results in parameters such as patient's age and gender, tumor prevalence, tumor diameter, and nuclear grade. However, the problems arising from the retrospective character of this study and the insufficient sampling and reporting limited the accuracy of pT examination. We believe that more accurate diagnoses and prognostic factor evaluations will be made by more widely using the international reporting systems in reporting process.

Conflict of interest: Authors declare that there is no conflict ofinterest between the authors of the article.

Financial conflict of interest: Authors declare that they did notreceive any financial support in this study.

Address correspondence to: Sirin Kucuk, Department of Pathology, Training and Research Hospital, Faculty of Medicine, Usak University, Usak, Turkey

e-mail: ata2012irin53@yahoo.com

Phone: 05056831285

\section{REFERENCES}

1. Bonsib SM. Neoplastik disease of the kidney. In: Bostwick DG. Eble JN (ed.) Urologic Surgical Pathology. 2. edition, Canada: Mosby, 2001;4-81.

2. Reuter VE, Tickoo SK. Adult Renal Tumors. In: Carter D, Greenson JK. Oberman HA, Reuter V. Stoler MH (ed.) Sternberg's Diagnostic Surgical Pathology. 4. edition, Philadelphia Lippincott Williams \& Wilkins, 2004;1955-2001.

3. Eble JN, Sauter G, Epstein JI, et al. Tumors of kidney. Tumors of the urinary system and male genital organs. In World Health Organization Classification of tumors. 4. edition IARC press: 2016;11-76.

4. Mohammadian M, Pakzad R, Towhidi F, et al. Incidence 
and mortality of kidney cancer and its relationship with HDI (Human development index) in the world in 2012. Clujul Medical 2017;90 (3):286-93.

5. Mahasin SZ, Aloudah N, Al-Surimi K, et al. Epidemiology profile of renal cell carcinoma: A 10-year patients' experience at King Abdulaziz Medical City, National Guard Health Affairs, Saudi Arabia. Urol Ann 2018;10(1):59-64.

6. Mikami S, Oya M, Mizuno R, et al. Recent advances in renal cell carcinoma from a pathological point of view. Pathology International 2016;66:481-90.

7. Casuscellia J, Vanob YN, Fridmanc WH, et al. Molecular classification of renal cell carcinoma and its implication in future clinical practice. Kidney Cancer 2017;1(1):3-13.

8. Nabi S, Kessler ER, Bernard B, et al. Renal cell carcinoma: A review of biology and pathophysiology. F1000Research 2018;307 (7):1-10.

9. Kentaro Inamura. Renal cell tumors: Understanding their molecular pathological epidemiology and the 2016 WHO Classification. Int J Mol Sci 2017;2195(18):2-15.

10. Muglia VF, Prando A. Renal cell carcinoma: Histological classification and correlation with imaging findings. Radiol Bras 2015;48(3):166-74.
11. Chaan SNg, Wood CG, Silverman PM, et al. Renal cell carcinoma: Diagnosis, staging, and surveillance. AJR 2008;191:1220-32.

12. Escudier B, Porta C, Schmidinge M. Renal cell carcinoma: ESMO clinical practice guidelines for diagnosis, treatment and follow-up. Annals of Oncology 2016;27(5):58-68.

13. Sandlund J, Oosterwijk E, Grankvit K, et al. Prognostic impact of carbonic anhydrase IX expression in human renal cell carcinoma. Journal Compilation 2007;100:556-60.

14. Abdel-Rahman O. Impact of histological subtype on outcomes of renal cell carcinoma patients. Journal of Drug Assesment. 2018;7(1):14-20.

15. Comperat E, Camparo P. Histological classification of malignant renal tumours at a time of major diagnostic and therapeutic changes. Diagnostic and Interventional Imaging 2012;93: 221-3. 